Nuntius Antiquus, Belo Horizonte, v. 12, n. 1, p. 91-116, 2016

\title{
Aristófanes e Platão: discursos sobre a mulher na Antiguidade
}

\section{Aristophanes and Plato: discourses on woman in Antiquity}

Karen Franklin

Universidade Federal do Paraná

Curitiba, PR - Brasil

franklinkaren@uol.com.br

Resumo: Este texto busca analisar o discurso sobre a mulher na Antiguidade, levando em conta dois universos distintos: primeiro, sob o prisma de Aristófanes com seu discurso cômico; segundo, sob o prisma de Platão com a ideia da guardiã na República. Ambos os discursos buscam expressar o universo feminino na Antiguidade, um utiliza a caricatura outro a excepcionalidade de posição. Porém, percebemos que nos dois discursos há a possibilidade de atuação de poderes femininos paralelos ao poder legislativo efetivo. Tecemos notas sobre a comédia aristofânica, uma forma literária que também poderá ser compreendida como um modo de revelar redes sociais informais entre as mulheres, bem como suas possibilidades de associação. $\mathrm{O}$ ideal de mulher pura $\mathrm{e}$ submissa expresso nos discursos legislativos da Antiguidade contrastam com o caricato apresentado por Aristófanes e pela construção da guardiã em Platão. Tais discursos demonstram que elas tinham mais liberdade do que transparecem os textos legislativos da época, fazendo-nos recolocar as questões da diferença entre a vida do discurso e a vida cotidiana.

Palavras-chave: mulher; Aristófanes; Platão.

Abstract: This text intends to analyze the discourse on women in antiquity, taking into account two different universes: first, through the prism of Aristophanes with his comic discourse; second, from the perspective of Plato with the idea of the female guardian in the 
Republic. Both discourses seek to express the feminine universe in ancient times, one uses caricature, the other uses the exceptionality of position. However, we realize that in both there is the acting possibility of feminine powers parallel to the effective legislature. We made notes on the Aristophanic comedy, a literary form which could also be understood as a way of revealing informal social networks among women as well as their possibilities of association. The ideal of pure and submissive woman expressed in the legislative discourses of antiquity contrast to the caricature presented by Aristophanes and by the construction of the female guardian in Plato. Such discourses show that they had more freedom than the legislation of the time shows, making us raise the issues of the difference between the life of discourse and everyday life.

Keywords: woman; Aristophanes; Plato.

Artigo recebido em 10 de janeiro de 2016 Aprovado para publicação em 2 de fevereiro de 2016

A base de uma sociedade está nos discursos que ela mesma faz sobre si. Desde a Antiguidade a dinâmica dos discursos mantém o povo em perspectiva, especialmente os atenienses que parecem ter a convicção de que "tudo depende do povo e o povo depende do discurso" (DECHANEL, 1867, p. 1). A possibilidade de proferir discursos na Grécia Antiga não era para todos, uma vez que até a formação dos jovens estava diretamente ligada a essa prova de cidadania e virtude. Conforme Dechanel (1867, p. 1), as únicas formas de proferir discursos em público em Atenas eram o teatro ou o tribunal. Ambas as instituições eram fundamentais, tinham verbas próprias e eram protegidas por lei a tal ponto que o orador que ousasse propor tocar nas verbas do teatro (théôricon-introduzido primitivamente por Péricles) poderia ser condenado à morte, pois proporcionar a possibilidade de frequentação da população às festas e apresentações teatrais era uma espécie de educação popular. O teatro era uma das instituições mais orgânicas da democracia ateniense, e seu financiamento deveria ser garantido a todos: ricos e pobres (DECHANEL, 1867, p. 2). A inspiração de um discurso era educadora. E é nesse panorama cultural que buscamos levantar dados para compreender como Aristófanes e Platão se conectam na tentativa de dar voz ou expressão social às mulheres, pois comumente não temos 
muitas ocorrências textuais de que elas tinham possibilidade de ter papeis ou posições de poder além do oikos.

Observar o discurso que emana do teatro como uma crítica filosófica pode aproximá-los de certo modo, pois na Antiguidade os diferentes discursos cumpriam um destino comunicativo, eram uma ode ao bem viver. Não havia áreas e limites a se respeitar. Apenas as artes humanas imperavam. $\mathrm{O}$ discurso sobre a mulher sob esses dois olhares é especial para nós, pois ao mesmo tempo que são distantes temporalmente fomentam novas discussões a respeito do tempo em que vivemos: Aristófanes, nas comédias que apresentam mulheres como protagonistas, Lisístrata, Assembleia de mulheres, Thesmofórias ${ }^{1}{ }^{\mathrm{e}}$ Platão em $A$ República, nos fazem refletir sobre a própria representação feminina na contemporaneidade. No entanto, entre eles e nós corre longo tempo, mudanças de posição e de perspectivas. Aqui buscamos observar a proposta subversiva de desestruturar o status quo vigente na Antiguidade e como estes dois discursos podem afetar a cultura do cotidiano, tanto de homens como de mulheres.

Cientes de que as noções do universo feminino na Antiguidade, especialmente na Atenas Clássica, estão ligadas à estrutura hierárquica da sociedade centrada no poder do kyrios, tomamos os argumentos da comédia de Aristófanes e da proposta filosófica de Platão para referendarmos o estranhamento com o poder da cultura presente em seus discursos. Todo o contributo da legislação, impregnada de penalidades que orientam o domínio sobre as mulheres, bem como a cultura que as normatiza e controla, imprimem sobre elas um discurso de poder administrativo tanto sobre suas mentes como sobre seus corpos, pois essa é a lei e esse é o costume. Parece que há pouca margem para desvios ou discursos alternativos, como os de Aristófanes e Platão.

Desta forma, para compreender uma certa dupla face do discurso sobre a mulher na Antiguidade, iniciaremos com Aristófanes e seus

\footnotetext{
${ }^{1}$ Podemos concordar que Lisistrata foi apresentada nas Leneas de 412; Assembleia de mulheres, ou Ecclesiazusae, foi apresentada nas Leneas de 392; e Thesmofórias nas Dionísias de 411. Esses dados são importantes para se pensar na contemporaneidade dos textos analisados, pois é correto supor que os assuntos aqui mencionados faziam parte das discussões da época, principalmente no caso de $A$ República, que apresenta argumento semelhante e certamente foi elaborada ao longo de vários anos. Para melhor compreender a tessitura da obra de Platão é pertinente consultar a Introdução de M. H. Rocha Pereira à tradução da República (1990).
} 
argumentos centrais nas peças que têm mulheres como protagonistas. Em seguida, abordaremos a proposta da guardiã na República de Platão, sua possível igualdade de educação e sua posição social na arquitetura de uma pólis justa.

\section{Comecemos pela tecitura de Aristófanes...}

Muitas são as novas leis elaboradas pelas mulheres que se propõe a administrar a cidade, criada por Aristófanes em Assembleia de mulheres, mas ele enaltece algo que era uma marca espartana: o estabelecimento do jantar comum. Esse fato parece trazer para a trama, além de uma situação nova, uma crítica aos próprios atenienses no uso comum dos recursos. Essa proposição da líder Praxágoras, a protagonista, introduz uma prática que referendava a ideia da comunidade de mulheres, argumento que parece pertencer ao universo conceitual da época. $\mathrm{O}$ sentido de comunidade se alarga nessa comédia ao ponto de que a comunidade das mulheres estabelece a primazia da satisfação das mais velhas antes das jovens e bonitas. $\mathrm{O}$ foco central aqui é certamente sexual; a métrica do discurso entre as mulheres mais velhas, o rapaz e sua amante estabelecem novas perspectivas na convivência entre todos. A cena encanta pela rapidez com que os argumentos vão agravando a situação de comunidade. A comicidade desenvolvida nesta cena do V Ato (ARISTOPHANE. Ecclesiazusae[Theatre], v. 640-725) mostra como algumas das proposições levantam problemas para a administração das mulheres e para a nova lei. Ao sugerir a inversão de papéis entre homens e mulheres, Aristófanes proporciona também uma crítica enfática à forma com que os homens administram a cidade: "hoje vemos, como o pedreiro que porta a argamassa, recebe três óbolos quando faz qualquer coisa pela pólis" (ARISTOPHANE. Ecclesiazusae[Theatre], v. 103), sinalizando a presença pagã nas decisões da cidade. Com essas palavras, o coro finaliza o primeiro Ato, indicando que essa é uma questão a ser discutida na Assembleia.

As intenções proclamadas no levante de Assembleia de mulheres também estão presentes em Lisístrata. Em ambas as peças é possível perceber que a proposição do controle político, administrativo e da guerra passa pelo poder do sexo e é nesse viés que a inversão de papéis busca se acentuar na comédia. A crítica social apresentada nessas comédias imprime um discurso subversivo, no qual as mulheres tomam o poder 
para si, legislam, manipulam as assembleias e, por fim, adquirem o poder "legítimo" de decidir os rumos da cidade. Compreende-se que é nos caminhos da oralidade que se legitima o poder, pois o pronunciamento de um discurso prenuncia a priori uma série de interesses, ou seja, esse gesto intenciona uma mudança efetiva (LIMA; CORDÃO, 2007, p. 271). Tal gesto é mantido tanto no discurso subversivo de Aristófanes, que dá voz às mulheres, como no silencioso projeto da guardiã de Platão. A consideração de que é no poder retórico que as decisões terão sua legitimação faz com que mulheres ensaiem discursos convincentes e patrióticos, reconstruindo o "savoir faire" dos costumes de tempos áureos.

Eu vou thes fazer ver que as mulheres são mais sensatas que nós. Primeiro elas lavam toda a lã na água quente, à moda antiga, e não podemos dizer que tem a mente fraca. Se a Pólis lhes imita e não fica sedenta de novidades, terá sucesso. Elas ficam sentadas para grelhar os alimentos, como antigamente; elas carregam jarros sobre suas cabeças, como antigamente; elas celebram as Thesmofórias, como antigamente; elas têm suas casas de cortesãs, como antigamente; [...] Assim, vamos lhes dar toda a administração e não perderemos de vista que enquanto mães elas com o coração pouparão o sangue dos cidadãos (ARISTOPHANE. Ecclesiazusae [Theatre], v. 213-234). ${ }^{2}$

Curioso e sarcástico Aristófanes imprime em peças, principalmente nas que mulheres são protagonistas, uma crítica aguda ao modo de vida cotidiano dos atenienses. Visivelmente nesta parte utiliza o saudosismo para marcar a tentativa de retorno a uma estabilidade longínqua e imaginária, ao mesmo tempo que propõe que elas subvertam a própria lógica do cotidiano. Assembleia de mulheres, Lisístrata e Thesmofórias estão permeadas de críticas políticas e de costumes, e parecem prenunciar associações ocultas das esposas atenienses através de seu discurso e suas tramas. Com a exacerbação da Guerra do Peloponeso, quase sem fim e sem vitórias, surge uma possibilidade: a de que as mulheres pudessem estabelecer redes sociais informais para efetivamente introduzirem novos elementos para se pensar o cotidiano. Segundo Lessa (2004, p.165), tais peças são uma espécie de documentação textual para se compreender a dinâmica das esposas atenienses que poderiam estabelecer redes sociais informais nas quais construíam uma espécie de discurso. Mesmo que

\footnotetext{
${ }^{2}$ Tradução minha, do francês, assim como as citações seguintes dos textos de Aristófanes.
} 
Aristófanes use de tom jocoso e caricato, o discurso feminino de suas peças concede espaço público às mulheres, lhes concedendo qualidades de logos métrico.

Podemos notar que a maioria dos textos clássicos associa as esposas e filhas legítimas com o ambiente interno do oikos, descrevendo como tarefas apropriadas à sua condição as relacionadas com a administração do lar. ${ }^{3}$ Aristófanes rompe com esse costume, jogando as esposas para a aventura da administração pública. A crítica à letargia dos maridos atenienses parece apimentar o argumento satírico. Mas é no comentário do Comissário de Lisístrata (ARISTOPHANE. Lisístrata [Theatre], v. 405-420) que vemos um exemplo do argumento perturbador e que tem origem nas tragédias euripianas: a facilitação ao adultério (moichos). Tal argumento parece funcionar também como uma crítica velada ao regime democrático, pois, com as atividades exteriores ao oikos, a casa ficaria desprotegida e pouco vigiada. A argumentação invoca o poder masculino: "Não reprimirei hoje a audácia dessas mulheres odiadas por Eurípides e pelos deuses? Que não tenha mais meus troféus na Tetrapole" (ARISTOPHAFANE. Lisístrata [Theatre], v. 280-285). A autoridade aqui invocada exprime toda a tensão entre os sexos.

A simples presença do sexo masculino já denota seu poder e é considerada o argumento forte daquele que tem voz sobre aquela que deve ser virtuosa pela obediência e pelo silêncio. Engendrar nas mulheres essas condições psicológicas de submissão faz com que o poder masculino se legitime sobre todas as atenienses. Aristófanes irrompe com o status quo vigente e profere a insurgência do poder feminino por meio da palavra, ou seja, em suas peças elas ousam proferir um discurso; discurso este que legitimaria sua condição de cidadã nos mesmos moldes dos homens. Para elas a condição de cidadania sempre esteve ligada à descendência legítima e à vida doméstica, Aristófanes subverte essa condição lhes atribuindo um discurso. A voz pública era um direito estrito da cidadania masculina. Para se ter direito à voz nas assembleias, as prerrogativas eram extensas, tanto que muitas vezes a cidadania poderia ser questionada, pois a legitimidade da descendência teria que ser comprovada para se ter esse direito. A lei de Sólon determinou que a cidadania estaria atrelada à descendência da esposa legítima do kyrios (chefe da casa), sendo assim, este deveria zelar pela educação dos filhos para que fossem capazes de

\footnotetext{
${ }^{3}$ Para uma descrição da condição da mulher na Antiguidade, vide Silva (1979-1980).
} 
proferir discursos em público. Isso quer dizer que ter o direito de se pronunciar em assembleia, era uma deferência máxima da cidadania, a legitimação de posição na sociedade. Parece que a caricatura criada por Aristófanes, que dá voz pública às mulheres, mantém uma certa coerência com a legitimidade, pois Praxágoras é esposa legítima de Blêpiro e Lisístrata é uma esposa ateniense. Não chega a dar voz a uma concubina, escrava ou cortesã, pois elas teriam outros papéis no controle geral das mulheres na cidade. Em Atenas, havia diferentes categorias de mulheres, que correspondiam a funções específicas das necessidades masculinas. Assim, a esposa legitima (gunêgametê), a concubina (pallakai) e a cortesã (hetairai) teciam papéis diversos na organização social da cidade e tinham reconhecidos direitos políticos diferentes para suas funções: "A condição do casamento reside na procriação. Temos as cortesãs para o prazer, as concubinas para os cuidados de todos os dias, as esposas para nos dar crianças legítimas e para guardar fielmente os bens da casa" (LORAUX, 2009 , p. 98). Diante da multiplicidade de mulheres que atuam na vida ateniense, a caricatura forjada por Aristófanes privilegia apenas classe das esposas, mantendo o protagonismo nas esposas legítimas, Praxágoras e Lisístrata. ${ }^{4}$ Corrobora de certa forma com o costume de que deve haver uma legitimidade cidadã para se ter voz pública. ${ }^{5}$

Essas peças de Aristófanes são interessantes sob o ponto de vista da subversão, porque nos trazem elementos de conflito autênticos, pois, ao mesmo tempo que existia uma legislação estrita sobre as dificuldades

\footnotetext{
${ }^{4}$ Podemos fazer referência à nota explicativa de Silva (1979-80, p. 97), que assinala que a sociedade era menos rigorosa com as escravas, estrangeiras e cortesãs, que gozavam de certa liberdade de vida e convívio, que a maioria das esposas não tinha acesso.

${ }^{5}$ Cf. Leão (2005, p. 53-65) - a relação entre os descendentes mais diretos no oikos regulava uma mútua obrigação: a paidotropia, relativa ao esforço da criação dos filhos pelos pais, e a gerotrophia, a obrigação de sustentar na velhice. No entanto, com a situação econômica da Ática, que atraía muitos imigrantes e a terra sendo em sua maior parte improdutiva, a insegurança se alastrava. Para incentivar o comércio marítimo e a indústria manufatureira, Sólon legisla na direção de que essa obrigação só estaria assegurada se o pai tivesse ensinado a seu filho um ofício, ou seja, garantindo-lhe uma boa educação capaz de assegurar-lhe também o sustento. Os filhos das concubinas, apesar de serem livres, não tinham o estatuto de cidadãos, o que contribuía para a relação que Aristófanes faz em sua peça As Aves em relação à gerotrophia, que cabia apenas aos filhos legítimos, herdeiros do patrimônio e da cidadania. Aristófanes capta o essencial da lei na obrigação dos filhos alimentarem os pais na velhice nesta paródia.
} 
de mobilidade social das mulheres, também havia a garantia legal do poder sobre elas:

Se uma mulher for dada em casamento legal pelo pai, ou pelo irmão dela (filho do mesmo pai), ou ainda por seu avô por parte de pai, seus filhos serão legítimos. Se não existir nenhum desses parentes e a mulher for uma herdeira, o seu tutor a desposará, mas se ela não for uma herdeira, qualquer um a quem seu tutor a confie há de tomá-la sob sua guarda (ARNAOUTOGLOU, 2003, p. 18).

Podemos compreender que um processo educativo garantiria a preparação dela para suportar esses termos do pater poder, pois era evidente cultuar o costume de que as esposas atenienses deviam estar sob tutela. "A educação que lhe era ministrada reduzia-se à prática de trabalhos domésticos e a uma formação moral, baseada sobretudo na ignorância das realidades da existência" (SILVA, 1979-80, p. 99). Isso certamente se ligava à sua futura condição de esposa, aquela responsável pela legitimidade da descendência. Aristófanes brinca justamente com esses elementos.

Se o domínio sobre a mulher se torna a principal ferramenta da manutenção do status quo no oikos e na polis, será exatamente este o argumento central das mulheres de Aristófanes: sua mobilidade social, sua liberdade sexual e sua liberdade em proferir discursos. Se costumeiramente educar as mulheres para subjugá-las era a forma eficiente de administrar os domínios do kyrios, Aristófanes brinca com isso apontando para as falhas educativas. Desde Homero as atividades femininas ligadas ao lar são intrinsecamente ligadas à própria descrição da personalidade feminina, exemplo disso está na construção da virtude ligada ao tecer por meio da descrição épica de duas figuras, Helena e Penélope. ${ }^{6}$ Elas impregnam a atividade do tecer de nobreza e virtuosidade, que em silêncio tecem sua própria condição de mulher. Tecer infinitamente, na perspectiva de Helena e Penélope, significa tomar consciência de sua condição de mulher em meio a atividade que lhe confere possibilidade em tecer um manto, uma teia, um silêncio, ou seja, estabelece o estatuto da esposa obediente. Nesse sentido, as mulheres de Aristófanes contrastam com

\footnotetext{
${ }^{6}$ Sobre o trabalho feminino do tecer na Antiguidade veja o interessante artigo de Maria de F. S. Silva, que relata detalhadamente os aspectos psicológicos de Helena e Penélope na trama de suas vidas. Cf. Silva (2006).
} 
a literatura trágica, que inculca um modo de ser mulher. Nos discursos trágicos são os homens que a caracterizam como um ser que sofre e se submete. A tragédia mostra toda a força da cultura e da lei sobre ela. Brincando com esses elementos, Aristófanes nos apresenta mulheres que protagonizam discursos libertários, políticos e pornográficos, todos em tom jocoso e caricato, porém abertos ao público.

Podemos considerar a dramaturgia na Antiguidade como uma forma de expressão eminentemente masculina. A ocorrência das questões femininas estava diretamente ligada às suposições masculinas sobre seu universo, desta forma a personagem feminina era convincente na medida em que preenchia essas suposições. Não ofender aos preceitos masculinos sobre o comportamento das mulheres também era uma forma de sucesso, pois colocava o público em sintonia com o que era expresso no palco (HUNTER, 2010, p. 117). Em uma sociedade fundada em regras tradicionais, mas já desgastada pela guerra, bem como pelas necessidades decorrentes dela, parece ter feito Aristófanes aguçar sua sensibilidade ao encenar as mudanças no cotidiano de Atenas.

$\mathrm{O}$ argumento e a forma caricata das comédias tinham seus críticos. Entre eles está Aristóteles, que em sua Poética aponta essa forma de arte como sendo de caráter inferior. Seu argumento vai na direção da evidência de que as peças de Aristófanes buscam a "imitação de homens [mulheres?] inferiores", e isso sempre estaria ligado ao ridículo. Diz Aristóteles: "O ridículo é apenas certo defeito, torpeza anódina e inocente; que bem o demonstra, por exemplo, a máscara cômica, que sendo feia e disforme, não tem [expressão] de dor" (ARISTÓTELES. Poética, V, §22). Parece que é o argumento que afeta aqui, pois diante de outras formas poéticas como a tragédia e a epopeia, que expressa melhor o verdadeiro espírito grego, a comédia se distancia de tudo o que é nobre e virtuoso. A comédia evidencia o cotidiano, aquilo que é o risível da vida, e parece ser justamente essa forma poética irônica a mais subversiva para dar voz pública às mulheres.

Aristófanes não poupa os lugares comuns, as preocupações cotidianas e as reações senso comum das mulheres. Em seu projeto cômico de libertar a mulher, imprime reações esperadas pela claque masculina. Esse ponto é interessante de se manter em perspectiva, o ponto de vista masculino. Exemplo disso é a resposta de Calonice à impaciência de Lisístrata: "Mas o que as mulheres poderiam fazer de sensato ou de brilhante? O que, nós, sempre sentadas, bem vestidas, 
cobertas de bugigangas, vestidos adornados de belo amarelo, nossas túnicas e sandálias?" (ARISTOPHANE. Lisístrata [Theatre], v. 42-45). Mesmo rompendo com o comportamento tradicional das esposas, Lisístrata tem que enfrentar a força da cultura, uma cultura tradicional de que elas são as detentoras e guardiãs. A ação das mulheres nessas comédias traz a descoberto um comportamento estranho, uma revolta que não lhes pertence ou, ao menos, não deveria lhes pertencer. O sentido impresso na crítica das protagonistas, tanto Lisístrata como Praxágoras, vai desde a impossibilidade do controle absoluto sobre as mulheres até a imperfeição denunciada na administração pública, ou seja, sua ação tende a ser global. Ao mesmo tempo que busca resgatar uma vida tradicional, imprime a força da mudança. Porém, o coquetismo feminino, que expressa um modo de ser da mulher, mantém sua força nas passagens cômicas e marca que elas não são homens; elas têm peculiaridades e não abrem mão delas, apenas reestabelecem as prioridades quando se propõe a administrar. Exaltar um discurso feminino preocupado exclusivamente com a aparência mantinha exposta sua inferioridade e imperfeição moral, ou seja, demonstrava que essa parecia ser sua verdadeira natureza.

Os deméritos das mulheres estão presentes nas tragédias, nas comédias e também nos discursos filosóficos, principalmente quando fazem referência à mulher como um ser dotado de preocupações superficiais e ardilosas em torno dos outros, bem como quando expõem o coquetismo exacerbado e a maquinação como a marca do feminino. Podemos considerar que é em Eurípides, como denunciam as mulheres das Thesmofórias (ARISTÓFANES. As mulheres que celebram as Tesmofórias, 1988, v. 385-430), e em Aristóteles que a naturalização desse discurso se intensifica, pois quando indica que, "em todas as espécies, o macho é evidentemente superior a fêmea: a espécie humana não é exceção" (ARISTÓTELES. Política, 1998, I, §12), o filósofo demarca uma naturalidade da superioridade masculina na tradição. Tais impressões de poder não estavam apenas nos costumes, mas principalmente no discurso. São os discursos sobre a mulher que protagonizam as "provas" de sua inferioridade, seja pela natureza, seja pela posição na sociedade. Por isso, manter o controle sobre a mulher, em particular, e sobre os grupos femininos, em geral, torna-se uma importante forma de manter o discurso ideológico masculino, pois é na força das expressões que a tradição se solidifica como regra. 
É possível pensar que as comédias de Aristófanes são uma concessão de espaço público às mulheres, pois, além delas ocuparem o espaço cênico, também ocupam a referência de costumes e o discurso como se fossem seus. Dominam, não mais pelo silêncio e pela obediência, mas pelo discurso, um discurso subversivo, revolucionário, e que parece contagiar a plateia. Mesmo conduzindo a cena com uma fala dirigida à plateia masculina, Aristófanes inova pela subversão da conduta feminina, mas não esquece de mesclar cenas de comportamentos esperados pela claque masculina. A dramaticidade da protagonista Lisístrata, indignada com suas companheiras, apresenta o contraponto ao argumento principal, justamente sobre a ideia da greve de sexo. As primeiras reações são adversas, pois representam o discurso masculino e euripidiano sobre elas.

Nosso sexo é intemperante! Tudo que as tragédias dizem sobre nós não é destituído de fundamento, porque somos boas em apenas uma coisa. Mas, ó minha querida lacedemônia [Lâmpito], mesmo tendo apenas você em meu lado, nós poderemos ainda reparar todo o mal! (ARISTOPHANE. Lysistrata [Theatre], v. 137-142)

A cena apresenta uma tensão interessante, pois nos parece que a protagonista tem dificuldades em argumentar com as companheiras. Apesar de apresentar a mais brilhante das ideias, Lisístrata tem problemas em convencer de imediato às outras mulheres, convencer de que o poder está com elas e que podem persuadir seus homens a respeito do fim da guerra. O comportamento esperado para elas está enraizado e faz parte de suas personalidades ao mesmo tempo em que corresponde ao discurso masculino sobre elas, ou seja, é o discurso que impera na forma legislativa que coloca a mulher dentro de uma estrutura de tutela e obediência. Uma estrutura que forja um vir a ser reforçado por comportamentos cotidianos que devem lhes pertencer.

De forma geral, a figura da mulher é retratada em sua forma "heroica" nas tragédias e epopeias, como por exemplo, Helena (de personalidade e beleza), Mélissa (esposa reclusa), Hipparquia (a filósofa) e Aspásia (a intelectual) que apresentam um caráter excepcional e exemplar, porém são distintas por sua condição privilegiada. Essa é uma diferença significativa para pensarmos no aporte discursivo de Aristófanes. A quem ele dá voz? Às esposas comuns, cansadas de guerra ou da conduta política de seus maridos. Ao retratar o cotidiano ateniense, expõem intuitivamente que as noções de público e privado 
serão discutidas em praça pública na voz feminina. ${ }^{7}$ Suas mulheres não são míticas nem excepcionais, elas são reais e adquirem uma postura proativa em relação à suas próprias vidas. Aristófanes prenuncia o que Lessa (2004) conceitua como redes sociais informais, ${ }^{8}$ por meio das quais as esposas atenienses estariam expostas a criar táticas de atuação independentes da permissão de seus maridos ou pais. Isso parece fazer sentido quando analisamos as peças de Aristófanes frente à legislação - que ainda está fortemente influenciada pela legislatura de Sólon e que definia o alcance mínimo do poder de uma mulher - e ao costume da época.

As cenas de Aristófanes denunciam a possibilidade de associação para a formação das redes sociais informais, por meio das quais mulheres poderiam capacitar-se para terem voz pública, deliberação e julgamento. O discurso e a deliberação sobre os assuntos da pólis, aliados ao poder da sedução costumeiro, pareciam um argumento fatal. Porém, em Assembleia de mulheres não há o enfrentamento direto como em Lisístrata ou Thesmofórias; lá elas se travestem e tomam o lugar dos homens para decidir a seu favor. Ocultas de sua condição e apenas depois da argumentação e da deliberação é que tomam o poder, um poder legítimo. Na voz das mulheres, a palavra de ordem é frear os ímpetos pela novidade, mudar em favor da tradição e corrigir os caminhos na política. A crítica inserida na peça elucida a capacidade de organização, apesar da legislação, dos costumes e dos hábitos gregos, mas a novidade também está presente na lei da nova administração feminina.

\footnotetext{
${ }^{7}$ Podemos assinalar a importância da opinião pública já mencionada por Aristóteles em 1404a na Retórica (2010), na qual se deve prestar atenção ao pronunciamento, não porque é justo em si, mas porque é necessário. O pronunciamento é uma forma de influenciar os rumos do governo e as decisões sobre ir ou não a guerra, é nesse sentido que alerta sobre a importância da opinião pública na administração.

${ }^{8}$ Considerando o conceito de rede social como um grupo organizado, com objetivos comuns, mas que tem seus membros individualmente em contato com outros membros de grupos diversos e que apresentam comportamentos independentes e uma subcultura que os distingue (citado por LESSA, 2004, p. 156). Pensamos aqui especialmente na ocorrência das festas religiosas, nas quais as mulheres tinham a oportunidade de reunião sem a tutela masculina, na preparação e execução, tendo também oportunidades de trocar opiniões sobre diversos outros assuntos. Sobre o tema, veja Bott (1990).
} 
Por seu turno, a proposta de Praxágoras é certeira para levar harmonia e segurança a todos na cidade; sua proposta é de mudança. Assim, o coro anuncia as necessidades da oralidade:

É para o bem comum que é preciso exercer a arte de bem falar, capaz de fazer brilhar um povo civilizado por todas as prosperidades que se pode apreciar na vida e de provar nesta ocasião. Porque a república está precisando de um sistema sabiamente coordenado (ARISTOPHANE. Ecclesiazusae[Theatre], v. 570-575).

Isso prenuncia a descrição da administração da protagonista ao seu marido Blêpiro, que, em êxtase ao final do diálogo, expressa: "Vamos! Marcharei, se você quiser, ao seu lado para atrair todos os olhares dos passantes sobre mim e comentarem: 'Você está vendo o marido da senhora governadora'?" (ARISTOPHANE. Ecclesiazusae [Theatre], v.725-727). As vantagens da descrição fazem Blêpiro se orgulhar das ideias e proposições da líder, ao mesmo tempo que reforçam o argumento de que elas podem se associar quando lhes interessa e que as redes sociais informais das esposas atenienses são possíveis. Aristófanes deixa claro que se o oikos era um limite, as estratégias engendradas a partir dele poderiam ser pontes para referendarem os argumentos de que elas poderiam ter poder. O comediógrafo esclarece que as mudanças na política ateniense e os fracassos sucessivos na guerra haviam mudado as perspectivas sociais. As mulheres adquirem voz em suas peças para chamar a atenção para os absurdos das decisões. As mulheres reais não tinham ausência de discurso, uma não voz. Seu discurso engendrado de silêncio, por vezes, poderia ser poderoso, como o retratado em suas comédias. No entanto, fica em suspenso a própria questão do controle das mulheres.

Como já apontado, a comédia aristofânica apresenta argumentos do cotidiano, da vida comum, seus dilemas e preocupações, e tende a apresentar mais explicitamente o argumento que buscava o riso da claque. O cômico faz a sua parte, debocha do legal e expõe uma realidade que, segundo a tradição, deveria estar em constante tutela. Isso está explícito nas palavras do comissário em Lisistrata, que aponta para a fragilidade de uma existência feminina não vigiada:

Não vamos às lojas dizendo ao joalheiro, por exemplo: "você fez um colar para minha mulher, [...] dançando ele caiu. Sou forçado a ir à Salamina; tente escapar uma noite de seu lazer, para ir concertá-lo. Um outro vai ao encontro de um sapateiro, de 
constituição boa e lhe diz: "Meu amigo, a alça machucou o dedo do delicado pé de minha mulher. Venha então à casa ao meio do dia e alargue-a." (ARISTOPHANE. Lysistrata [Theatre], v. 405-419)

Tratamentos como esses parecem endereçados a uma plateia heterogênea, pessoas de todos os tipos e classes sociais, mas que certamente têm em comum a preocupação com os costumes e com a legalidade das relações expostas ali, principalmente os referentes aos adultérios (moichos).

O discurso cômico de Aristófanes retrata as mulheres de forma caricata, mas ativa; anacronicamente ao discurso da tradição, retratado nos preceitos legais, que lhes impõem o silêncio e a contenção. O que se espera delas é a passividade de sua natureza e sua contrição aos costumes. Que sucumbam ao ideal desejado para elas! Quando Aristófanes apresenta o argumento central de Lisístrata e sua solução para a guerra, demonstra ao mesmo tempo a analogia entre oikos e pólis, expressos na engenhosidade da trama da protagonista. As ações das mulheres buscam aproximar sua expertise doméstica do ambiente público, pois em Assembleia de mulheres elas também tomam a Acrópole como um oikos alargado. A atuação feminina é uma extensão de seu poder doméstico, e poderá fazer a diferença e resolver um problema aparentemente insolúvel.

Tal discurso encena o poder feminino para além de suas fronteiras domésticas, ao mesmo tempo que acentua a zombaria e a ironia contida no argumento central do poder de associação: a inversão dos papéis na cidade e o anúncio da vida feliz por meio da administração feminina. Com isso, o êxito da administração doméstica é exportado para a administração pública em Assembleia de mulheres. Ali elas têm bom senso, gerem bem as riquezas e preservam a religiosidade; 9 logo, realizariam uma administração exitosa. É principalmente aqui que Aristófanes expõe as relações possíveis entre as mulheres fora do oikos; porém, o referencial doméstico é mantido como paradigma. É possível ver isso em Assembleia, na qual sua ação na pólis é similar à ação no oikos, pois manterão as

\footnotetext{
${ }^{9} \mathrm{O}$ discurso de Lisístrata recorre a alguns elementos da retórica clássica, buscando obter a persuasividade da questão, a partir da disposição do enunciado (greve de sexo), percorrendo a pronunciação por meio das consequências requeridas (fim da guerra e consequentemente a volta ao sexo livre). Isso ocorre também em As mulheres que celebram as Tesmofórias (1988), na qual Aristófanes brinda com insurgências contra Eurípedes e suas personagens femininas exacerbadas de sentimentalismo e ungidas de destino.
} 
mesmas atividades de sempre, ou seja, vão tecer, cozinhar, cuidar dos filhos e dos homens da cidade, só que agora no poder e com voz. Esse poder de voz que aparece no discurso cômico tem um valor crítico forte, pois se refere à gestão da vida, da cultura e, principalmente, refere-se às decisões que não podem mais ser admitidas.

Fomentar a possibilidade de que as mulheres poderiam associarse para tomarem o poder denunciava uma fragilidade no controle sobre elas. Nessas peças, Aristófanes demonstra que as redes sociais informais se materializam mesmo que por intermédio da caricatura, pois em sua trama parece evidente que as mulheres são as candidatas mais apropriadas a administrarem a cidade, bem como a obterem êxito nas relações sociais entre as classes. É preciso compreender que uma pluralidade de mulheres vivia na Atenas Clássica e que suas possibilidades de estabelecer associações eram reais; no entanto, as esposas das classes mais abastadas estavam submetidas à fortaleza de um discurso próprio e silencioso: a legislação e a cultura. Por essas duas forças as esposas não tinham nem poder nem voz; eram submetidas à tutela e ao controle, além de serem caracterizadas pela tragédia como seres conturbados e ímpios. ${ }^{10}$ Em contrapartida, não estavam todas as mulheres nessa situação: as plebeias com poucos recursos gozavam de certa liberdade. Para assegurar o sustendo dos filhos, elas tinham uma vida no exterior, trabalhavam nos campos ou em pequenos negócios, como a vendedora de flores, apresentada em Thesmofórias (ARISTÓFANES. As mulheres que celebram as Tesmofórias, 1988, v. 445-455). Podiam falar livremente com suas semelhantes e estabelecer contatos com homens da sociedade. Da mesma forma, as espartanas tinham uma vida voltada ao exterior. Sua educação instituía os exercícios físicos e as práticas para a vida em comunidade. Em comum com as atenienses havia apenas a missão de dar filhos legítimos à cidade (SILVA, 1979-80, p.103). Manter o equilíbrio entre prisão e permissão à mulher era argumento para a sátira e a ironia. Porém, uma nuvem de possibilidade se efetiva neste século V a.C., momento em que Aristófanes anuncia novos tempos, pois para algumas

\footnotetext{
${ }^{10}$ Vide tragédias de Eurípides, a quem Aristófanes endossa críticas, principalmente em As mulheres que celebram as Tesmofórias (1988), colocando-o pessoalmente no centro do argumento.
} 
mulheres existia a garantia da cidadania (esposa legítima) e para outras a certeza da exclusão de direitos (hetera, pallake ${ }^{11}$ ).

\section{Seguimos com a arquitetura argumentativa de Platão}

Podemos elencar muitas obras que corroboram com o tratamento direcionado às mulheres, seja pela sua natureza ou por sua condição social, mas o que nos move aqui é estabelecer um horizonte paralelo do discurso legal sobre a mulher na Antiguidade. Assim, buscamos também na filosofia aberturas de tratamento e consideração sobre o universo feminino capaz de restabelecer algum apreço e significado para além de sua condição social estabelecida na lei. E é em Platão que encontramos uma dessas ocorrências. No diálogo República, ${ }^{12}$ podemos verificar uma dessas postulações, que, mesmo não sendo a única, vamos nos concentrar nela, principalmente por retratar o que Aristófanes já havia mencionado: a comunidade de mulheres e seus desdobramentos.

Em meio a padrões de discurso comum sobre a relação entre homens e mulheres, ${ }^{13}$ Platão instituiu a ideia da guardiã. Esse diálogo apresenta a proposta de subverter o status quo para estabelecer uma nova ordem. Ao supor a possibilidade de igualdade entre homens e mulheres por meio da educação, surge a figura da guardiã no Estado

\footnotetext{
${ }^{11}$ A posição das concubinas era muito interessante do ponto de vista político, pois parecem ser as companheiras ideais para um homem de prestígio; uma mulher educada, que tem uma beleza expressiva e que pode ser apresentada em público (banquetes). Geralmente eram estrangeiras que podiam ter uma educação elevada e que sabiam desvencilhar-se dos percalços sociais, ou também eram escravas de sua casa, formando uma grande família. Como não tinham relações com valor de casamento, seus relacionamentos tendiam a ser também mercantis; o homem garantia seu sustento e ela mantinha sua fidelidade e companheirismo. Nenhuma dessas relações fora do casamento tinha efeito legal, mesmo desenvolvendo relações de amor e afeição e porventura uma descendência ilegítima. Frutos desses relacionamentos não tinham uma posição legal na cidade e geralmente eram excluídos de voz pública pela origem ilegítima.

${ }^{12}$ Utilizaremos somente a tradução de Maria Helena da R. Pereira (1990).

${ }^{13}$ Apenas para exemplificar, cito o diálogo entre Sócrates e Céfalo no livro I da República, quando este expressa que já não necessita mais fazer amor com uma mulher, pois livrou-se dessa escravatura. Em 329b-c, Céfalo lembra as palavras do poeta Sófocles: "[...] sinto-me felicíssimo por the ter escapado, como quem fugiu de um amo delirante e selvagem"; em contrapartida, no livro V, aborda a questão da guardiã.
} 
justo. ${ }^{14} \mathrm{~A}$ proposta de construção do novo projeto de pólis parece provocar o advento da necessidade da guardiã. Dessa necessidade intelectiva surge a oportunidade de discutir a igualdade entre os sexos. Assim, uma mulher de cultura superior - que aprenderia a arte da guerra, as disciplinas formativas e a dialética igualmente aos homens, e que, no final do processo educativo, estaria supostamente habilitada a concorrer ao governo - faz-se necessária. Certamente é uma proposta completamente inovadora, senão do foro da literatura cômica, do foro da filosofia ou da utopia. Se por um lado Platão estabelece, com sua inovação, uma reafirmação da unidade da cidade justa e sua capacidade de enfrentar as adversidades, por outro, impõe noções estranhas a essa mesma cidade.

A proposta de refundar a cidade está fundamentada nas questões da justiça (PLATÃO. República, 369a), mas na sequência da construção do projeto irá estabelecer tipos de homens para essa cidade justa. E é nesta construção harmônica e dispare de sociedade que a ideia subversiva de igualdade entre homens e mulheres surge: educação igualitária para algumas naturezas (PLATÃO. República, 451d). Sua intervenção inicia na seleção pela natureza (PLATÂO. República, 451e) e desenvolve-se ao ponto de refundar toda a estrutura social a partir da igualdade da execução das tarefas.

Platão constrói a argumentação dessa educação igualitária a partir da "comunidade de mulheres", descrita no livro V da República, que de fato é o mesmo argumento de Assembleia de mulheres, de Aristófanes. Utilizando a proposição de que, se homens e mulheres executam as mesmas tarefas, devem ter a mesma educação, Platão avança na compreensão de uma estrutura igualitária para os sexos. Parece considerar que o argumento da natureza distinta é frágil quando se trata de naturezas superiores. Mesmo concordando que as naturezas são distintas (PLATÃO. República, 453e), que "a da mulher é diferente da do homem. Porém, agora afirmamos que naturezas diversas devem executar a mesma tarefa", Platão conduz a discussão de modo a esclarecer que não é a diferença em si o problema relativo à igualdade das tarefas, mas sim o tipo de natureza diversa que falamos. E assim conclui:

Se, porém, se vir que a diferença consiste apenas no fato de a mulher dar à luz e o homem procriar, nem por isso diremos que está bem demonstrado que a mulher difere do homem em

${ }^{14}$ Ver Franklin (2010). 
relação ao que dizemos, mas continuaremos a pensar que nossos guardiões e suas mulheres devem desempenhar as mesmas funções (PLATÃO. República, 454e).

A partir disso Platão considera em seu projeto as naturezas de homem e mulher como não idênticas, mas como aparentadas na classe dos guardiões. Essa relação não equânime não o inibe em construir a possibilidade de imprimir na mulher a natureza da guardiã, pois de certa forma ela será amiga do saber, tal qual o guardião. Ela apresenta uma natureza naturalmente dotada para a aprendizagem, que facilmente compreende para além do que aprende (PLATÃO. República, 455b), ou seja, ela tem uma inteligência superior. Por fim, depois de muito discutir sobre a natureza de homens e mulheres, a conclusão de Platão sobre o objetivo de sua atuação na cidade justa é uma e a mesma:

Não há na administração da cidade nenhuma ocupação, meu amigo, própria da mulher, enquanto mulher, nem do homem, enquanto homem, mas as qualidades naturais estão distribuídas de modo semelhante em ambos os seres, e a mulher participa de todas as atividades, de acordo com sua natureza, e o homem também, conquanto em todas elas a mulher é mais débil do que o homem (PLATÃO. República, 455d-e).

Parece-nos que mesmo compreendendo a estrutura de seu projeto de cidade justa, Platão não se rende efetivamente à inovação de subverter totalmente os fundamentos enraizados na cultura e na legislação. Certamente podemos postular que há uma correlação com a comédia aristofânica, pois os argumentos são semelhantes em relação à comunidade de mulheres. A possibilidade de associação das mulheres atenienses não é de fato uma perspectiva platônica, porém, para o bem comum, essa ideia parece derivar da necessidade de forjar a harmonia da cidade justa. Possivelmente, aos olhos de Platão, os rumores de redes sociais de poder, de mulheres surgindo em tribunais tendo direito à voz, pareciam apenas argumento para a comédia; por isso, em sua obra elas deveriam estar sob controle. Mesmo as mulheres de qualidades superiores devem estar em harmonia e submetidas à ordem. Assim, a igualdade das mulheres na República tem endereço certo: uma função. São guardiãs da cidade, obedecem às leis e sempre serão consideradas mais débeis que os homens. Aparenta-nos que Platão reconhece a possibilidade de associação das redes informais das esposas atenienses quando educadas 
da mesma forma que os homens, porém não acredita nelas. Mesmo sem intenção ele contribui para fortalecer o argumento de que tais redes de ação seriam possíveis para certas naturezas. Obviamente, não se referia a todas as mulheres atenienses, mas àquelas que tinham algum destaque e influência moral, política ou administrativa. Supomos que, postulando o alcance dessas redes na pólis, Platão constrói o argumento filosófico diante do equilíbrio entre o guardião e a guardiã e elege como compatível à sua proposta uma mulher capaz de desenvolver as mesmas tarefas de guarda da cidade. Ela é necessária ao seu Estado justo, pois é companheira ideal para a classe governante ${ }^{15}$, que, ao enquadrar-se ao conjunto perfeito pela inteligência e virtude, também estaria sob controle. Sob tal aspecto, podemos dizer que o projeto busca também conter a ação feminina, ao colocar a mulher em padrões inéditos e subversivos, e corrobora com os padrões de absoluto controle, seja na vida pública, seja na vida privada. Ao propor a incorporação pública das mulheres à estrutura de seu novo Estado, Platão ao mesmo tempo enfrenta o status quo da Atenas democrática e busca conter um possível (e imaginário) aumento do poder feminino. Ciente de que este último argumento não corresponde ao que se conhece como a realidade das mulheres atenienses ${ }^{16}$, acreditamos que estivesse consciente dos perigos das redes informais de ação (FRANKLIN, 2010, p. 141), mesmo que por meio do deboche impresso nas comédias de Aristófanes.

Quando Platão convoca as mulheres de natureza superior para a vida pública na função de guardiãs, inaugura na filosofia um olhar sobre a mulher que está para além do seu papel de reprodutora da espécie. Ela

${ }^{15}$ Um bom exemplo seria Telesilla, a mulher que organiza com sucesso a defesa de Argos dos ataques do espartano Cleomenes. Ela arma todos os homens e mulheres para defenderem a cidade. Ciente de estratégias de guerra, Telesilla leva as mulheres armadas ao recanto por onde avançam os espartanos, e estes, ao avistarem um exército de mulheres, recuam. O motivo pode ser discutido: seja para não vencerem sobre um exército de mulheres, seja para não serem derrotados por elas (LIGHTMAN; LIGHTMAN, 2008, p. 307-308).

${ }^{16}$ Inevitavelmente temos de considerar que as atenienses da época de Platão não tinham qualquer representatividade pública ou jurídica. Conforme Annas (1994, p. 232), "uma herdeira, por exemplo, transmitia suas propriedades ao seu parente masculino mais próximo, que poderia lhe esposar para preservar os bens familiares. As mulheres respeitáveis eram mantidas numa parte separada da casa e raramente saíam (mesmo as compras eram feitas por homens), salvo para as festas". 
adquire, ainda que teórica e idealmente, uma função de mediadora entre o real e o ideal. Mesmo compreendendo que a proposta de redimensionar as atribuições das esposas, quiçá das mulheres em geral na construção da Cidade justa, só faz sentido no conjunto de sua produção intelectual, é possível pensar que Platão, ao subverter esse traço da vida ateniense, busca afirmativamente uma colocação e uma legitimação pública para as esposas intelectualmente ativas que viviam marginalizadas e escondidas no oikos. Se a elas cabia a legitimação de toda a estrutura eugênica e a legitimidade da cidadania, não poderiam ser consideradas párias do conjunto perfeito. Ao publicizar as atividades femininas na ideia de Guardiã, Platão desfaz o poder e o alcance das possíveis redes informais de ação, ajustando qualquer poder paralelo ao poder justo e constituído, submetendo-o ao crivo público e perfeito. Na busca por desconstruir qualquer possibilidade de ação fora da estrutura da Cidade justa, a administração teria total controle sobre o universo feminino e masculino.

Qualquer ideia de igualdade entre homens e mulheres é inusitada na Cultura Antiga, pois não há evidência de que havia possibilidade dessa ocorrência senão pela proposição de um discurso, quer filosófico, quer cômico. Isso significa que a abertura para uma percepção de noções diversas ao que comumente se concebe da mulher na Antiguidade passa, necessariamente, pela análise de certos discursos "não oficiais", seja de cunho utópico ou cômico. Mas também pode revelar uma mudança de comportamento social em relação a muitos conceitos, principalmente devido às condições históricas vividas, como a Guerra do Peloponeso, por exemplo. O sistema jurídico, a cultura e os costumes estavam de acordo com o jugo das mulheres, de que elas deveriam estar submetidas à ordem e à administração de seu kyrios. $\mathrm{O}$ poder sobre elas parecia ser total. Esse era o costume e essa era a lei, mas havia algo acontecendo que chamava a atenção para os discursos. Como assinala Louraux (2009, p.99), para a esposa o mundo exterior é o mundo dos outros, lugar para o qual deve se fechar, se proteger, quer dos olhares, quer dos acontecimentos. No entanto, o mundo reage por meio das regras e das condições que lhe permitem assumir, nos espaços e nas formas que lhe são atribuídas, uma excelência particular, que lhe rende uma marca de discrição e reserva. Nesse sentido, podemos pensar que a forma como Platão publiciza o fazer da guardiã lhe retira a necessidade de esconderse do exterior, mas mantém a condição de reserva e discrição diante do poder masculino da cidade. Se não há mais, na classe dos guardiões, 
diferença nas funções, mantêm-se os preceitos da "natureza" como forma de controle e submissão. Enfatizo que o mais significativo aqui é propor à mulher de natureza superior uma educação igualitária. Esse parece ser o discurso mais avassalador referente a ela: "A educação para a mulher, para ser guardiã, não será uma para preparar os homens, e outra para as mulheres, sobretudo porque toma a seu cargo uma natureza idêntica" (PLATÃO. República, 456c-d). Certamente a possibilidade de igualdade em Platão está diretamente ligada a uma perfeita arquitetura da polis justa. É preciso estruturar a ocorrência das "melhores mulheres entre as mulheres" (456e) que "tomarão parte na guerra e em tudo o mais que respeite a cidade" (PLATÃO. República, 457a). Propostas como essas figuram nos discursos, principalmente pela eficiência de Esparta na guerra, já que suas mulheres contribuem sobremaneira para dar bons guerreiros à cidade e produzir um estado de segurança interna. Sendo ativas, parecem ser o modelo ideal para a cidade que é desenhada mediante o discurso. ${ }^{17}$ Certamente no universo conceitual de Platão está o relato da reflexão frente ao mundo que o afeta, aos argumentos que circulam no século $\mathrm{V}$ a.C. e às temáticas que envolvem poetas, filósofos e oradores em geral.

\section{Um elo interessante...}

Para finalizar nossas reflexões, buscamos abordar segmentos e suposições sobre as mulheres na Antiguidade como uma forma de voltar o olhar para um tempo distante. Mas é preciso perguntar: O que as comédias de Aristófanes nos revelam sobre as mulheres? Como a ideia da guardiã em Platão pode revelar algo de novo sobre a mulher na Antiguidade? Para responder, ao menos de modo parcial, a tais questões, é importante presentificar algumas notícias. Seguramente as mulheres não eram prisioneiras, frequentavam os espaços públicos, representações teatrais, banquetes e eram ouvintes de discursos. Mas de quais mulheres estamos a falar, das esposas legítimas, concubinas, prostitutas ou escravas, enfim, quais delas poderiam circular livremente? Como já assinalamos, algumas mulheres tinham de fato uma vida exterior, como comerciantes e vendedoras; no entanto não eram da classe mais abastada. Sua necessidade indicava um certo fracasso social. Quanto às esposas da classe mais alta,

\footnotetext{
${ }^{17}$ Para a crítica a esse desenho da cidade ideal, vide Nussbaum (2004).
} 
não é possível comprovar que transitavam livremente, mas é possível ter presente que em alguns momentos elas saíam do oikos legitimamente. Nesses momentos podemos supor que poderiam criar táticas e modos de agir que as permitiam criar espaços de atuação, fazendo surgir uma prática distanciada do discurso ideológico masculino. O que Lessa (2004, p.164) chama de redes sociais informais das esposas legítimas na verdade pode ser interpretado também como formas de aquisição de voz, mesmo que silenciosa. Os cultos religiosos (Thesmofórias ${ }^{18}$ ) dos quais elas participavam, com exclusividade, poderiam muito bem ser a oportunidade para consolidar tais compromissos e solidariedade. As comédias aristofânicas contribuem sobremaneira para referendar as teses das redes informais entre as mulheres na Antiguidade, bem como fazem abertamente uma crítica social dirigida aos governantes da cidade.

Da mesma forma que faz Aristófanes, o argumento de Platão na construção da figura da guardiã nos leva a crer em possíveis associações femininas. Longe de buscar a aprovação da claque masculina, propõe com sua postulação de igualdade na educação da mulher de classe superior um questionamento sobre a eficiência do sistema de tutela e submissão. Tanto um como outro apresentam o comportamento não ortodoxo das mulheres como argumento central de discursos, seja o cômico, seja o filosófico, mas ambos abrem a possibilidade de pensamento sobre a mulher na Antiguidade em outros termos. A crítica impressa à realidade que está nas postulações de Platão sobre o Estado justo apresentam uma direção interessante. A questão das mulheres é apenas mais uma no rol de indagações e reflexões filosóficas que surgem na República, ${ }^{19}$ e que nos

\footnotetext{
${ }^{18}$ Segundo Silva (1988, p. 11-12), tal comédia aristofânica tem o objetivo de caricaturar ainda mais o universo feminino sob o véu da reação. Segundo a perspectiva da comédia, Eurípides é o poeta que traz a mulher à cena para falar mal dela. O seu interesse em retirar o ateniense de seu canto recatado é acentuar a maledicência. Naturalmente a caricatura insiste no vício, na má-formação da personalidade feminina, que se encarna nas figuras simbólicas de Fedra e Melanipa, mulheres adúlteras e perjuras. Mesmo sendo absolutamente parcial - porque omite as virtudes de Alceste, Ifigênia e Andrômeda -, esta caricatura concilia modernidade de um tema euripidiano com a tradição da sátira feminista, tão velha quanto Hesíodo.

${ }^{19}$ Sobre este ponto, resume Nussbaum (2004, p. 32): “O processo em construção tem cinco elementos principais: a divisão do trabalho, a eliminação da família nuclear, a reforma da poesia e a educação elementar, a proposta de igualdade para as mulheres, e, finalmente, a famosa proposta de que a cidade deveria ser governada por filósofos".
} 
fazem estar alertas para possibilidades de associações informais. Nesse caso, as especulações são permitidas: será que havia em casas abastadas mulheres que apresentavam comportamentos próximos aos representados nas peças de Aristófanes? Uma herdeira (epikleros) poderia apresentar rompantes de liberdade e intenções de voz? Por sua origem, educação e condição financeira, teríamos correlatos da natureza guardiã de Platão? Haveria a possibilidade de mulheres submetidas às leis atenienses realmente não acatarem o poder do kyrios?

\section{Enfim...}

Dificilmente poderemos responder a estas questões. Mas podemos conceber que, da mesma forma que hoje, não havia uma unanimidade de comportamentos na Antiguidade, seja de homens ou mulheres. Assim, por esse prisma, talvez a tese das redes sociais informais mencionada responda, em parte, às questões. Pela infinidade de tipos femininos que circulavam em Atenas, alguns desses comportamentos poderiam ocorrer esporadicamente, como ocorrem até hoje. Uma herdeira ou uma viúva abastada poderia, sem dúvida, influenciar em decisões políticas, pois, se as guerras ou a paz passavam por decisões também econômicas, seu dinheiro poderia fazer a diferença. Certamente, podemos conceber que, apesar de não terem direito à voz, algumas mulheres se pronunciavam nos banquetes e em reuniões privadas, seja com argumentos políticos, seja com argumentos filosóficos. Por exemplo, uma figura como Aspásia, mulher de Péricles, não passaria despercebida no centro político e social de Atenas. Embora seja difícil comprovar tais hipóteses, podemos indagar sua possibilidade e ocorrência tecendo ligações diretas e indiretas, bem como formulando ligações entre o riso aristofânico e alguns argumentos platônicos.

O ponto central que levantamos aqui, qual seja, o discurso sobre a mulher na Antiguidade, por meio da intercorrência e aproximação de argumentos do projeto filosófico platônico e da comédia de Aristófanes, sobre as mulheres e suas possibilidades, as comunidades de mulheres e a administração feminina da cidade apenas reforçam a realidade da comunicação feminina frente ao que se legisla sobre ela. Estabelece a nuance do poder do discurso frente ao poder do silêncio. Ao apresentarmos o discurso cômico como uma evocação, mesmo que caricata, dessa inversão de valores, buscamos trazer à luz reflexões que possibilitem verificar a associação livre entre as mulheres na Antiguidade. 
Ao desvelar a inabilidade masculina da condução da vida cotidiana, das decisões políticas e das relações, ao mesmo tempo em que desvela que o discurso das mulheres é real e poderoso, Aristófanes revela outro prisma da cultura ateniense. É uma denúncia de empoderamento que a aprisiona ao oikos apenas pela força da lei e não de fato, pois elas mesmas conseguem, por intermédio de suas redes informais, atuar publicamente e sob o jugo masculino. No mesmo sentido, Platão apresenta a suposição de igualdade entre homens e mulheres da classe dos guardiões, provocando uma abertura para a compreensão de que haviam mulheres consideradas capazes de se destacarem pela inteligência e pela areté. Esta possibilidade lhe confere um estatuto digno e poderoso, capaz de guardar não apenas a cidade, mas toda uma geração futura. Mesmo considerando a acusação de Julia Annas (1994, p.220), de que Platão não promove uma cultura comum, ao destinar a educação semelhante para os sexos, e sim apenas para a classe dos guardiões, prescrevendo às outras classes a manutenção das diferenças e a tutela aos governantes, penso que ele avança ao supor uma igualdade de gênero, pois possibilita, mesmo que em projeto, o empoderamento da mulher por meio de um discurso.

\section{Referências}

ANNAS, J. Introduction à la République de Platon. Tradução de Béatrice Han; prefácio de J. Brunschwig. Paris: PUF, 1994.

ARISTÓFANES. As mulheres que celebram as Tesmofórias. Introdução, versão do grego e notas de Maria de Fátima de Sousa e Silva. 2. ed. Corrigida e aumentada, Coimbra: Instituto Nacional de Investigação Científica, 1988.

ARISTOPHANE. Théatre. Trad. M. J. Alfonsi. Paris: Flammarion, [s.d.] Tome second.

ARISTÓTELES. Poética. Tradução da versão inglesa de W. D. Ross: Leonel Vallandro e Gerard Bornheim. São Paulo: Nova Cultural, 1991. (Coleção Os Pensadores).

ARISTÓTELES. Política.Tradução Roberto Leal Ferreira. São Paulo: Martins Fontes, 1998. 
ARISTÓTELES. Retórica. Prefácio e introdução de Manuel Alexandre Júnior, trad. e notas Manuel Alexandre Júnior et al.4. ed. Lisboa: Imprensa Nacional-Casa da Moeda, 2010.

ARNAOUTOGLOU, I. Leis da Grécia Antiga. Tradução Ordep Trindade Serra e Rosiléa Pizzaro Carnélós. São Paulo: Odysseus, 2003.

BOTT, E. Familia y Red Social.Tradução de R. Gobernado. Madrid: Taurus, 1990.

DESCHANEL, M. Émile. Études sur Aristophane. Paris: Hachette, 1867.

FRANKLIN, K. O papel da mulher na cidade: atividades femininas na Antiguidade e a idéia de guardiã em Platão. In: CORNELI, Gabrieli (Org.). Representações da Cidade Antiga: categorias históricas e discursos filosóficos. Lisboa: Universidade de Coimbra/ Clássica Digitalia/ Archai, 2010. p. 135-146.

HUNTER, R. L. A comédia Nova da Grécia e de Roma. Tradução de Rodrigo Tadeu Gonçalves; Guilherme Gontijo Flores et alli. Curitiba: Editora da UFPR, 2010.

LEÃO, D. F. Sólon e a legislação em matéria de direito familiar. In: MORA, C. M. (Coord). Ut par delicto sit poena: crime e justiça na Antiguidade. Aveiro: Centro de Línguas e Culturas, Universidade de Aveiro, 2005. p. 53-65.

LESSA, F. de S. O feminino em Atenas. Rio de Janeiro: Mauad, 2004.

LIMA, M. V. de; CORDÃO, M. P. de S. Discursos ciceronianos: a oratória como estratégia política na Roma Antiga. Clássica: Revista Brasileira de Estudos Clássicos/Sociedade Brasileira de Estudos Clássicos, Belo Horizonte, v. 20, n. 2, 2007.

LIGHTMAN, M. ; LIGHTMAN, B. A to Z of ancient Greek and Roman women. rev. ed. New York: Facts on File, 2008.

LOURAUX, N. (Org.) La Gréce au Feminin, Paris: Belles Lettres, 2009.

NUSSBAUM, M. A República de Platão: a boa sociedade e a deformação do desejo. Tradução de Ana Carolina da Costa Fonseca et alli. Porto Alegre: Ed. Bestiário, 2004.

PLATÃO. República. Tradução de Maria Helena da R. Pereira. 6. ed. Lisboa: Fundação Calouste Gulbenkian, 1990. 
SILVA, M. de F. S. O trabalho feminino na Grécia Antiga: lenda e realidade. Clássica: Revista Brasileira de estudos clássicos/Sociedade Brasileira de Estudos Clássicos, Belo Horizonte, v.20, n. 2, p. 182-201, 2006.

SILVA, M. de F. S. A posição social da mulher na comédia de Aristófanes. Humanitas, Coimbra, n. 31-32, p. 97-114, 1979-1980. 